May, 1997

\title{
WHY CAN'T A COLLEGE BE MORE LIKE A FIRM?
}

\author{
Gordon C. Winston* $^{*}$ \\ Williams College
}

In My Fair Lady, Rex Harrison asks plaintively, "Why can't a woman be more like a man?" If she were, he thought, she'd be a whole lot easier to understand and to live with. In academic board rooms and state and federal legislative chambers, the question is "Why can't a college be more like a firm?" If it were, so goes the hope, it would be a whole lot easier to understand and to live with.

Some answers are becoming clear -- why colleges and universities are, in some very basic ways, inescapably different from business firms. Like men and women, there are a number of important similarities. But like men and women, we can get into a whole lot of trouble if we're not clear about both the similarities and the differences.

There's some urgency to this question because the changes sweeping over higher education are going to be very hard to evaluate and harder to predict and control if we

\footnotetext{
* The Andrew W. Mellon Foundation supported the work that lies behind this paper through its generous support of the Williams Project on the Economics of Higher Education. An early version was presented at the Stanford Forum in Aspen in October, 1996 and it came away much improved. Comments and encouragement came, too, from Frank Oakley, Hank Payne, Sarah Turner, Larry Litten, Jim Kolesar, Jo Procter, Ethan Lewis, Dave Breneman, Dick Chait, John Chandler, James Shulman, Bill Massey, Joel Myerson, Morty Schapiro, and Mel Elfin.
} 
aren't clear about how to understand these institutions and this 'industry.' In his 1994 Nobel lecture, Doug North described the importance of the "shared mental models" we use to make sense out of the world because they go far to determine what we see and what we don't see and what we make of it all. An inaccurate mental model of higher education disserves us all. If we think colleges are just like firms when they're importantly different from firms, we will make a hash of it.

But colleges and universities DO sell goods and services, like education, for a price, like tuition, and they make those goods and services with purchased inputs and hired workers, like fuel oil and professors, and they use a lot of plant and equipment, like classrooms and labs and parks and computers, and they compete hard for customers and for faculty inputs.

So if it walks like a firm and it talks like a firm, isn't it a firm? The answer, pretty clearly, is No. Or, Not in A Very Simple Way.

There are half a dozen economic characteristics that make colleges and universities different -- fundamentally, economically different -- from the for-profit business firms that shape economists' theories and trustees' and legislators' intuitions. Three are due to Henry Hansmann, a Yale Law professor and economist, and concern non-profit firms in general; three are specific to colleges and universities.

Hansmann described the defining characteristic of nonprofit firms -- both legally and economically -- as what he called a "non-distribution constraint." Nonprofit firms can make profits, but they can't distribute those profits to their owners -- their stockholders -- and, indeed, they don't have any owners.

One concomitant of this constraint is that nonprofit firms are most useful and most often found in markets where there's asymmetric information -- where customers don't really know what they're buying (or often whether they've bought anything at all), like 
CARE packages for Zaire or, often, day care or nursing home services. These are "trust markets."

Another concomitant -- widely and critically noted -- is that there's reduced pressure on management to operate efficiently. With no profits to distribute, neither stockholders nor corporate raiders can put a fear of inefficiency into nonprofit managers.

If the local Ford dealer had to operate under a non-distribution constraint, you'd know that he wasn't earning any personal profit from servicing your car and you'd therefore have more reason to trust him when he said you needed a brake job; but he might be more likely to do sloppy work.

That goes to Hansmann's second key characteristic: While conceding their imperfection, he described the managers of nonprofit firms as being motivated by different and typically more idealistic goals than the managers of normal business firms.

This is a useful but messy idea. On the one hand "everybody knows" that the profit maximization motives we attribute to businessmen are an oversimplification -- that business people are sometimes motivated by complicated idealistic ends, too. On the other hand, Estelle James argued persuasively some twenty years ago that managers of nonprofits often corrupt the idealistic aims of their organizations to slide profits over from the activities that earn them to other activities that the managers like better -- so, according to James, they may use profits from undergraduate education to cross-subsidize graduate education or faculty research or a Rose Bowl team.

But still there remains a significant difference in what drives the managers of nonprofits. The managers of colleges and universities are more idealistically motivated -they care about educational excellence, about student opportunity and access, about diversity. Essentially idealistic motives clearly underlie need-based financial aid, for one concrete and expensive instance [see Bowen and Breneman]. 
Third, Hansmann identified two different kinds of nonprofits, distinguished by their revenue sources:

"Donative nonprofits" rely for revenues on charitable donations in service of ideological purposes -- churches are donative nonprofits and so is CARE or the local PBS station. Those donors, like the managers, believe in the purposes of these firms so they donate their money to support them.

“Commercial nonprofits" sell a product for a price -- hospitals and medical insurance and, again, nursing homes are commercial nonprofits.

But then colleges and universities are a mix -- they are "donative-commercial nonprofits" in Hansmann's terms. Part of their income comes from sales revenues -tuition and fees -- and part of it comes from charitable contributions, past and present -endowment income and gifts and government appropriations.

With these two sources of income, donative-commercial nonprofits don't have to charge a price that covers their production costs. To the extent that they've got donative revenues, they can give their customers a subsidy, by selling them an expensive product at a cheap price. And colleges and universities do just that. In 1991, the average student at the average college in the US paid $\$ 3,100$ for an education that cost $\$ 10,600$ to produce. So she got a subsidy of $\$ 7,500$. And, I think surprisingly, there's little difference, on average, between public and private schools -- average subsidies were $\$ 7,800$ and $\$ 7,200$, respectively. We're used to government subsidies intended to affect people's choices, but here we have massive private subsidies, too.

If that Ford dealer were acting like the typical college or university, he'd be selling the Taurus that costs him $\$ 20,000$ to put on the showroom floor for a price of $\$ 6,000$. Not on a year-end clearance, but all the time. Year after year. He might charge his poor customers a lower price than his full-pay sticker price buyers, but on average he'd get $\$ 6,000$ for the $\$ 20,000$ car. He'd be able to do it of course -- and keep on doing it -- 
because someone cared enough about what he's doing to be willing donate the other $\$ 14,000$ per car: a private donor or state legislature. The end result is that the selling price is less than production costs, in clear violation of the laws of Economics 101.

Fourth, to a remarkable extent, people simply don't really know what they're buying. And they can't find out until long after the fact. The idea that higher education represents "an investment in human capital" is more significant than is often realized since investment decisions -- even for the hard-headed businessman building a factory -- are inherently freighted with uncertainty; indeed, with "unknowability." Keynes threw in the towel, saying that investment behavior was dominated by 'animal spirits.' For an investment in higher education, the outcome can't be known for twenty to thirty years, if then, and, if that weren't problem enough, it's a once-in-a-lifetime decision that can't be corrected next time around ("I went to Harvard the first time, but frankly it wasn't worth it so I'll get my next undergraduate education at University of Montana") and it's a decision that people often make protectively on behalf of their beloved children. So the 'perfectly informed customer' of economic theory is nowhere to be seen. Buying a college education is more like buying a cancer cure than a car or a house. There's a strong tendency to avoid regret and play it safe and buy what everyone considers "the best," if you can afford it -- reputation and animal hunches loom large in the final decision.

The fifth characteristic involves the way it's produced: higher education is made by a very strange technology, a "customer-input technology." Colleges and universities can buy one important input to their production only from their own customers -- students help educate students. Good fellow-students, other things being equal, will lead to a better education than poor fellow-students. These are the "peer effects" that show up regularly in empirical studies of college quality -- and they're certainly apparent to those of us who teach.

This production technology is really very unusual. Think of the Ford dealer, again. It's as if the Taurus you bought would become a better car -- the steering would become 
more responsive and it would need fewer repairs and hold the road better -- if the other people buying Tauruses were better drivers. If they were very good, you'd wind up with a Lexus or Mercedes.

So because it affects the quality of the product they make, colleges and universities care about who they sell their product to. Since students differ in their ability to provide this input -- to contribute to the education of their fellow students -- a good college wants to sell only to good students, those who will do it well. While fierce selection at the top colleges makes the news stories, even the least selective institutions look hard at student quality and exclude the poorest fitting. This is not the anonymous, indifferent market of economic theory, but using it, Rothschild and White showed that when schools simultaneously buy from and sell to their students, it's at a net price that reflects both of those transactions.

The last economic fact on my list has to do with "heterogeneity." Not surprisingly, schools differ very much. And they differ very much in the price they charge for a dollar's worth of their product. So you can buy that Taurus at different prices -- or you can buy BMWs and used Geos. A BMW, in fact, will cost you less than a used Geo. It all rests on the fact that some schools are wealthy -- depending relatively little on commercial revenues from tuition because they have ample donative revenues from gifts and endowments and physical plant and legislatures -- and some schools are poor. So some schools give their students very large subsidies and some give very little. Again, in 1991, the ten percent of US schools with the largest student subsidies gave the average student a subsidy worth $\$ 21,000$ a year; those with the smallest subsidies, gave $\$ 1,500$. I've come to suspect that this -- these differences in schools' ability to pay subsidies to their students -- is the most fundamental element in the economics of higher education.

Now, let me put these pieces together in a rough model of higher education. It has three parts. 
The first piece of the model says that schools use their donative resources -- their ability to subsidize students -- to influence the quality of the students they get. It works like this:

- A large subsidy means a better bargain for students -- they get more for their money: more and better facilities, more distinguished professors, more student services... Students recognize this. So subsidies influence student demand, applicants respond to a good deal. And larger subsidies go with higher demand.

- If the school controls its size, student demand translates into excess demand -a queue.

- That queue of would-be customers allows a school to pick and choose, they select students for their qualities in helping to educate other students.

- Because of the difficulty any student faces in knowing what he's buying and what it will do for him, a school's reputation becomes critically important.

- But it all starts with differences in the schools' wealth -- their access to nontuition, donative resources. And it ends with a highly differentiated set of colleges whose initially different wealth has turned into differences in student quality. This may, indeed, be the main way that differences in dollar resources translate into differences in college quality -- studies like Sarah Turner's show strong institutional SAT effects on returns to education but little or no direct expenditure effects.

- The hierarchy appears, too, to have supported quite different ways of producing higher education; different ways of organizing that use or economize on scarce student quality. Those schools that can command a great 
deal of student quality organize themselves to take advantage of its abundance -- they amplify its effects by increasing student interaction -- they are residential, they have small classes and non-vocational curricula, they're often isolated, etc. Schools with little of student quality organize themselves to get by without it, de-emphasizing student interaction -- they have more part-time students who are older, more commuters, and, in the extreme, more of distance learning where student interaction can play little role, if any.

The second piece of the model is a feedback of student quality on student demand and therefore on student quality, and so on... a fact of central importance to Admissions Offices and US News. (Two nice articles in Change and The Wall Street Journal described colleges' efforts to fudge the data on their student quality -- so important is it to their standing in the market and their ability to sell their product.) So student quality is a direct signal of college quality -- "these are the people who'll educate you." There is also an anticipated halo or network effect as one becomes first a student and then an alumn, admitted to the networks of that school's graduates "with all the rights, honors, and privileges appertaining thereto" (to borrow from Williams' commencement rhetoric).

The third piece of the model asks what a market of such firms looks like? It's certainly not flat, like the competitive market. It's a hierarchy. But the hierarchy isn't based on size or number of firms or number of customers, as in conventional oligopolies or oligopsonies of economic theory. It's by the size of their donative wealth -- the endowments and appropriations and gifts that support their ability to give an educational subsidy and then compound that advantage by the student quality feedback. Wealth per student. The rich get richer and the rich have been getting richer for a long time. It's no accident that higher education was the first market Frank and Cook identified as "winnertake-all.”

So the higher education market, already separated along regional lines -- and sometimes ideological lines among denominational schools -- is also highly hierarchical, differentiated by donative wealth into vaguely delineated and overlapping bands that have 
little competitive interaction. At the top are schools characterized by large subsidies and excess demand and student selectivity; at the bottom are schools characterized by excess supply; in the middle are the schools facing quality/quantity tradeoffs and the unpleasant choices of enrollment management.

There are a whole lot of numbers lying behind all this but maybe they can be summarized in these three graphs. They are based on most of the 3,000 or so colleges and universities in the US and the IPEDS data they reported to the government for 1990-91. (Anyone who wants more data and fewer pictures can see the Discussion Papers from the Williams Project listed at the end.)

\section{Subsidies, Costs, and Prices}

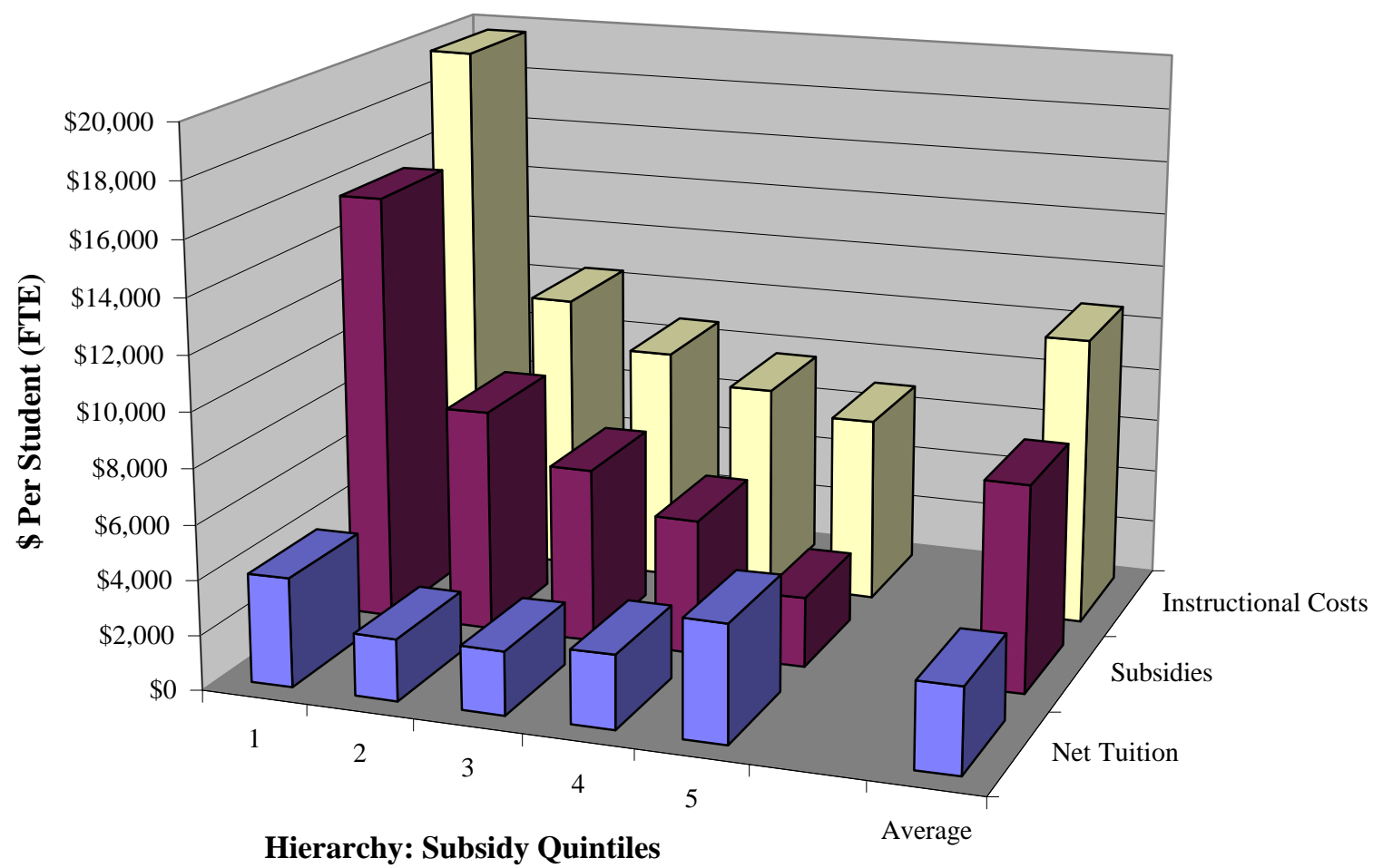




\section{Subsidies and Student Quality}

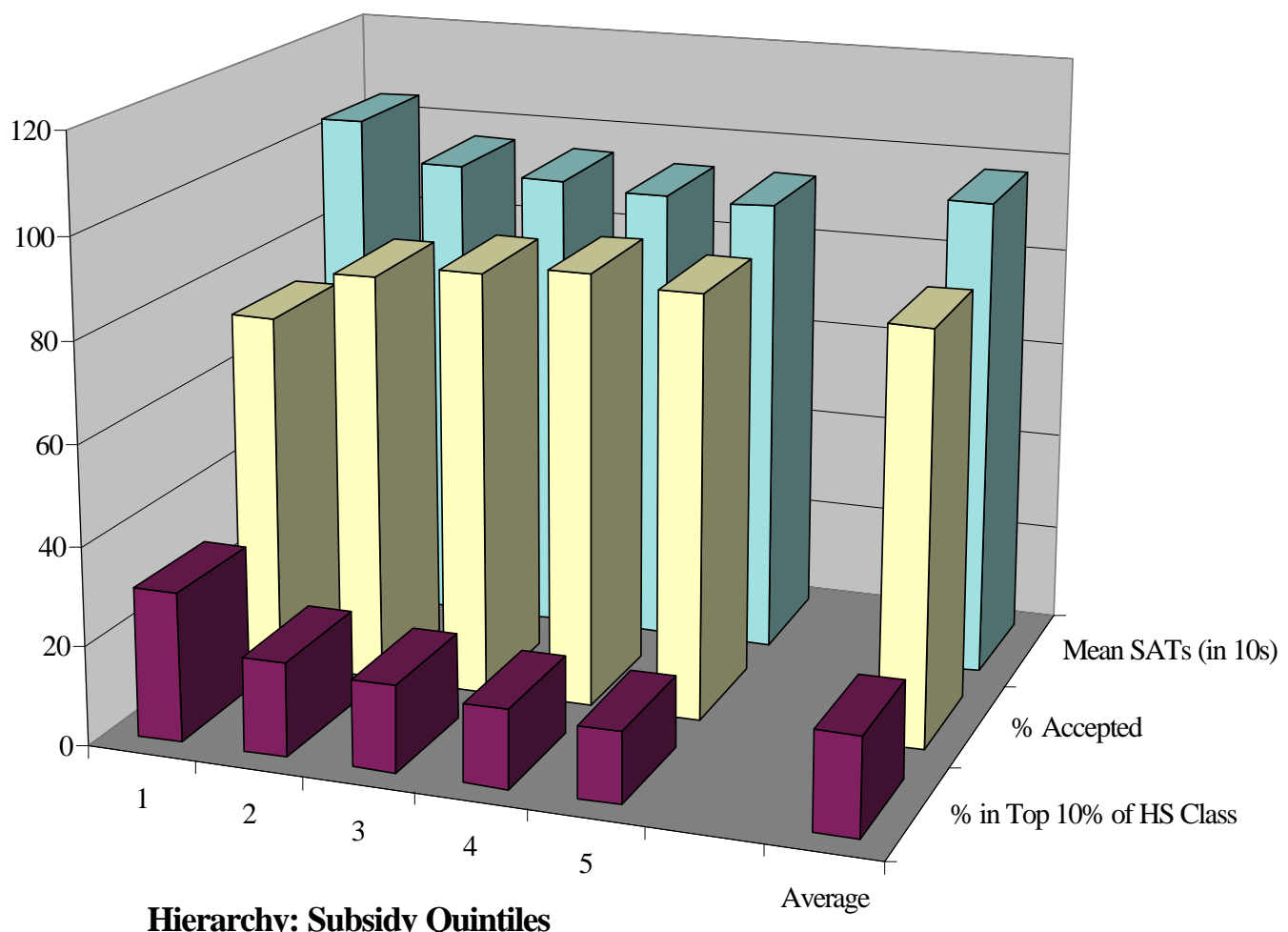

Hierarchy: Subsidy Quintiles

\section{Educational "Technology"}

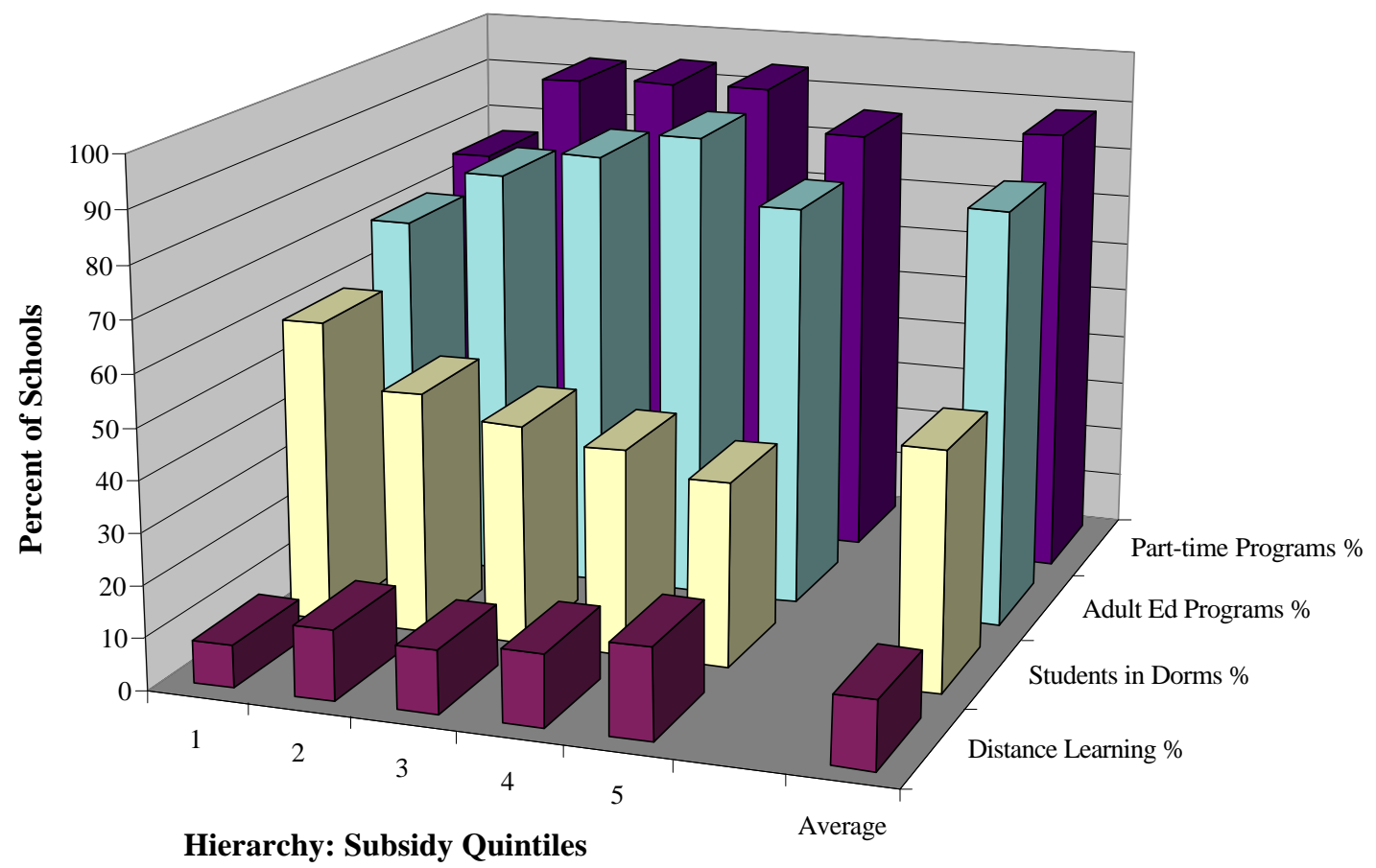


The first graph pictures the average yearly subsidy provided by US colleges and universities, the net price that students actually pay, and the amount spent on their education. (Only two of these are independent -- subsidies are measured as educational cost per student minus net price.) The three bars on the far right describe the fact already noted that, on average over all schools, the cost of a year's education is $\$ 10,600$ for which the student pays $\$ 3,100$ so he gets a subsidy of $\$ 7,500$. The bars on the left give the same information but for the hierarchy of schools, ranked by the size of their student subsidies -their wealth -- from richest to poorest, left to right. Quintile rankings are pretty crude -deciles tell a better story, especially about the very top winner-take-all schools -- but quintiles are easier to read (and all of these relationships within the subsidy hierarchy are very significant, statistically). This figure shows that as subsidies decline, so does spending on a student's education. And so, for a while, does the price the student has to pay for his education. But, surprisingly I think, that net price falls only at the top, then it turns up in the bottom two quintiles -- students at the schools with the smallest subsidies that spend the least on their students' educations, make them pay more out of pocket than those further up the hierarchy.

In the next panel, measures of student quality are plotted against the same subsidy hierarchy. Most familiar are schools' average SAT scores (that fall from 1041 in the top quintile to 931 in the bottom) and the share of applicants accepted (that rises from $73 \%$ in the top quintile to $86 \%$ in the bottom). The graph also shows a decline in the proportion of freshmen coming from the top $10 \%$ of their high school class (from $30 \%$ at the top to $14 \%$ at the bottom). Other measures like the proportion of freshmen who score over 600 on the Math SAT tell the same story but clutter the graph. (All of these relationships are statistically quite significant.)

The last panel pictures some ready indicators of "educational technology" to show how schools arrange themselves to take advantage of student quality, or compensate for its absence. It also includes some measures that would act primarily to increase the demand pool -- there is considerable overlap in these. So the colleges with less of student 
quality are markedly less residential (from $60 \%$ of undergraduates in dorms at the top to $36 \%$ at the bottom) and more dependent on distance learning ( $8 \%$ of the schools at the top have such programs, $18 \%$ at the bottom) and vocational degree programs ( $7 \%$ to $12 \%$ ). The proportion of schools with adult education programs rises (from $70 \%$ at the top to more than $90 \%$ in the fourth quintile) before falling back (to $79 \%$ in the fifth). Part- time programs also rise to the middle of the ranking and then fall.

So what? I think the most basic answer to that always-crucial question remains that of understanding. If we aren't clear about how higher education functions, we will be unlikely to see or predict or evaluate the changes that are overtaking us. There's that useful old saw that we rarely get in trouble because of things we don't know -- we get into trouble because of things we think we know, but we don't. We can ill afford to be wrong about the economic structure of higher education, confusing it with a for-profit industry.

But that's pretty abstract. So let me end with some more concrete illustrations:

- We're facing an increase in enrollments over the next decade estimated at $10 \%$ to $30 \%$. That kind of demand increase would be cause for dancing in the streets in any for-profit industry. But for higher education, it is cause, instead, for genuine panic. If it comes to pass that 3 million more students enter US colleges and universities, they will bring with them (based on our 1991 numbers) an additional $\$ 9.3$ billion in net tuition revenues, but they will also bring an additional $\$ 32.0$ billion in costs -- if quality is to be maintained at 1991 levels -- and that will require $\$ 22.7$ billion of additional non-tuition resources. From somewhere. Our for-profit intuition doesn't prepare us for a dilemma like this.

- The "snooties" at the very top of the hierarchy appear to be insulated from market forces -- they can give very large subsidies that generate long queues of highly able applicants from whom they select only the best. For-profit firms with all that demand would invite immediate competitors, but in the Alice-in-Wonderland economics of higher education, competitors don't appear because, tradition and reputation aside, they would have to provide their students with huge subsidies to do so. They would 
have to sell their product for about 25 cents on the dollar of cost and do it, not just to break into the market, but from day-one onward. So are the colleges and universities at the top of the hierarchy impervious to market pressures? Probably not, but that isn't a question that can be answered on the basis of theories and intuitions from the for-profit sector.

- For a firm, increased size often brings economies of scale -- fixed costs are spread over more and more output. But for a college that's dependent on endowment and existing physical plant to support its student subsidies -- as most private schools are -increased size spreads those fixed resources over more and more students, reducing the average subsidy each one can get. Smaller subsidies, less demand. And if that weren't reason enough to be wary of expansion, increased size reduces selectivity from any given applicant pool. Less selectivity, lower student quality, lower educational quality. So for two good reasons, private schools have long been reluctant to expand. Public schools, in contrast, have usually been supported by “capitation" -- appropriations tied to enrollments -- to encourage expansion, hence citizen access to higher education. They escape the gloomy arithmetic of a larger denominator that rules the private sector. But that's changing. Capitation is being replaced by fixed block grants to public colleges, as in the California system, and as they accumulate more endowment wealth, public colleges and universities will increasingly have the same incentives the private schools have had to restrict access -more students will come to mean more costs but not more income. So if the trend to block grants continues, it can be anticipated that public institutions will behave increasingly like private ones with access restricted by size and selectivity both.

It may seem paradoxical that these insights into the economic uniqueness of higher education rest solely on economic analysis -- on using its ideas and stucture to see the limitations of conventional economic analysis and intuition. But, without careful attention to costs and prices and production technologies and, especially to markets -- for students and student quality and faculty quality -- higher education would remain very hard to understand and those making economic decisions about higher education (legislators, 
donors, trustees, administrators) would be hard pressed to avoid disastrous errors in addressing the challenges that lie ahead. 


\section{$\underline{\text { References }}$}

Bowen, William G. and David Breneman. "Student Aid: Price Discount or Educational Investment?” Brookings Review 11 (Winter 1993): 28-31.

Clotfelter, Charles T. Buying the Best: Cost Escalation in Elite Higher Education. Princeton University Press. 1996b.

Cook, Philip J. and Robert H. Frank, "The Growing Concentration of Top Students in Elite Schools," in Clotfelter, Charles T. and Michael Rothschild, eds. Studies of Supply and Demand in Higher Education. A National Bureau of Economic Research Project Report. Chicago and London: University of Chicago Press, 1993.

Hansmann, Henry. "The Rationale for Exempting Nonprofit organizations from Corporate Income Taxation.” Yale Law Journal 91 (November 1981): 54-100.

James, Estelle. "Product Mix and Cost Disaggregation: A Reinterpretation of the Economics of Higher Education." Journal of Human Resources 13 (Spring 1978): 15786.

Rose-Ackerman, Susan. "Altruism, Nonprofits and Economic Theory.” Journal of Economic Literature 34 (June 1996): 701-728.

Rothschild, Michael and Lawrence J. White. "The Analytics of Pricing in Higher Education and Other Services in Which Customers are Inputs." Journal of Political Economy 103 (June 1995): 573-86.

Stecklow, Steve. "Cheat Sheets: Colleges Inflate SATs and Graduation Rates in Popular Guidebooks.” Wall Street Journal, 5 April 1995, Sec A, p. 1.

Turner, Sarah. "A Note on Changes in the Returns to College Quality." University of Michigan, 1996.

Webster, David S. "Rankings of Undergraduate Education In U.S.News and World Report and Money: Are They Any Good?" Change. March/April, 1992, pp. 19-31.

Winston, Gordon C. and Ivan Yen. "Costs, Prices, Subsidies, and Aid in US Higher Education." Discussion Paper Number 32, The Williams Project on the Economics of Higher Education, July 1995.

Winston, Gordon C. "The Economic Structure of Higher Education: Subsidies, Customer Inputs, and Hierarchy," Discussion Paper Number 40, The Williams Project on the Economics of Higher Education, November, 1996 